

\section{Meditações de departamento público}

Vitor Rodrigues de Almeida

Universidade Federal de Santa Maria 
Dia 4 de janeiro de 2017. Passava das oito e meia da manhã e o dia se mostrava quente. Ainda bem que ventava. A senhora atendia por Odete ou Cleusa e trabalhava na Fundação Gaúcha do Trabalho e Ação Social, lugar onde poucos de fato trabalham, sendo duro. Ela tinha um rosto redondo, murcho e oleoso com as sobrancelhas vorazmente pintadas de preto. A testa dela derretia com um ventilador que se esforçava num canto. O urbano típico dessa época do ano. Seu nariz era grande e brilhante como uma laranja madura, dessas que na infância apanhávamos direto do pé e que agora compramos no mercado por R\$1,67 o quilo. Mas não gosto de falar em dinheiro.

O olhar era baço e tinha um tipo de fundura que não havia em palheta de artista nenhum. Sentada à mesa ela fitava a ponta dos dedos, atenta, como se olhasse um poço. É que ela tinha acabado de raspar o coco da cabeça à procura de caspa.

A seborreia não arrancou dela a vaidade. Ela vestia um vestido colorido de um tecido brilhante, que quando andava quase mostrava o começo das pernas gordas e contaminadas pelas varizes. Quase pude sentir o esforço que o 
sangue fazia para subir e descer e assim manter aquele pedaço de carne vivo, porque é o que somos no final das contas. Mas será? Biologia é interessante, mas filosofia é fascinação.

Os pés eram maiores que o sapato de salto e se espremiam nas tiras prateadas refletidas nas unhas pintadas de vermelho. Vermelho Encarnado Cintilante. Como diriam os velhos que conheci já velhos e que, sem saber porquê, tive a impressão de que nunca iriam morrer. Até que morreram de causas desconhecidas deixando consequências inimagináveis, compositoras da melodia que toca em mim agora. O resto é segredo. Tão secreto que não se sabe se existe ou se alguém me inventou e eu sigo inventando e reinventando.

Dia 5 de janeiro, Miguel do Rosário escreveu que o governo brasileiro bate recorde de gastos com publicidade. Dia 6, Amanda Mars escreve que os serviços de inteligência acusam Putin de tentar ajudar Trump a chegar à Casa Branca. De que adianta ser espectador do mundo? Esse era o tipo de pergunta que fazia Odete ou Cleusa girar os anéis nos dedos de nervosismo. Ela usava ao menos cinco anéis diferentes nas mãos. Eram distribuídos entre dedos indicadores, médios e mínimos. Li algumas partes de um livro que comprei em uma loja de incensos. Mentira. Pedi emprestado a um amigo, de quem nunca vou esquecer, e a quem nunca vou devolver. O livro se chama Quiromancia: o futuro está em suas mãos. Numa dessas partes dizia que anéis dourados usados 
no indicador fortalecem a autoridade, no dedo médio filtram as energias negativas e no dedo mínimo chamam fortuna. Nem ela nem eu sabíamos se a quiromancia era verdadeira e sobretudo se a quiromancia do livro era verdadeira. Mas será? O próprio fato de não saber se sim ou se não me intriga. Essa área nebulosa entre o sim e o não. O saber e o não saber. O sempre e o nunca. A vida e a morte. Saber que não sabia fomentava a crença, da senhora, nesse caso. A coisa em si ela sabia que existia. Sabia quase sensorialmente, só não chamava de Deus pois não era católica, chamava de astrologia, quiromancia, tarô, cartomante Claudinha...

Sobre a mesa de trabalho, que era separada das demais - o que dava uma certa autoridade à mulher - havia uma miniatura de árvore com tronco e galhos feitos de arame contorcido e, em vez de folhas, pequenas lascas de quartzo roxo, alguns papéis empilhados, uma xícara de plástico com algumas canetas, e dois telefones que tocaram várias vezes e eram atendidos por ela com um mesmo prazer inóspito:

- Bom dia. Sim, sim, mudamos pra Silva, sim. De nada.

Ela bebia café em uma xícara florida, de boca larga, que permitia a entrada da ponta das bolachas redondas e secas. A vagueza do gosto nostálgico da massa mole feita de Bolacha Maria e café morno remexendo na boca era seu deleite. Quando retirava as bolachas do pacote, duas a duas, e metia na xícara 
num movimento rápido, sem olhar, a pulseira dourada e comprida batia a alça da xícara ressoando no ambiente também inóspito.

Todos dali iam religiosamente até sua mesa, logo que chegavam, para lhe estalar os lábios na bochecha e elogiar sua cor de cabelo ou conversar alguma amenidade sem sentido. Odete ou Cleusa, corada, às vezes até arreganhava a boca finíssima com rugas verticais que demonstrava nos lábios os inúmeros cigarros fumados na vida. Inúmeros. Alguns acesos no filtro. A imagem de si mesma que tinha, tinha apenas a partir do outro. E eles sabiam disso. Ela não. Ela apenas passava os dias. Não conseguia enxergar o desejo íntimo de revirar dos olhos que esses outros tinham ao conversar com ela.

Na próxima quarta-feira, dia 11, volto lá para retirar minha Carteira de Trabalho e Previdência Social. Até lá não sei mais de Odete ou Cleusa, a partir daqui somos só nós dois e o tempo. Sete e dois. A essa hora da manhã a vida começa a se tornar um pouco mais desconfortável. Mas por que comecei com a história de Odete ou Cleusa? Para suspender a minha? A palavra "suspenso" vêm do latim suspënsus e significa pendurado, mantido no alto. Como quando alguém que se atira de um precipício pendurado só por uma corda no pescoço. Talvez seja por isso que os filmes de tensão são chamados de suspense.

Comecei essa história para terminá-la. Talvez tenha começado por pura ânsia pelo final, já que a ideia dela começou pelo fim em minha cabeça: irei 
matá-la. Tenho a mania de chegar nas coisas de maneira indireta. Cassiano também. Fico admirado com isso nele, dentre tantas outras coisas. Acho um gesto natural e sutil. Não sei se ele sabe disso. Não importa. Falar sobre o Cassiano é como o sentimento de ir até a rua de corrida atrás da reitoria da universidade de manhã cedo. Ou sentar sozinho no lugar mais alto da arquibancada do Centro de Educação Física só para ver o sol batendo na estrutura. Não dá vontade de acabar. Como não quero transformar o texto em um texto de amor, paro por aqui.

Odete ou Cleusa poderia morrer no chão de uma rua de pedra, atropelada e esperançosa como a heroína de inocência pisada e de miséria anônima. Poderia ser em um restaurante popular cheio. Os cacos de vidro do prato se misturando com a comida ainda quente e o corpo já frio. Poderia ser em casa espancada pelo marido e a história eventualmente se tornaria, portanto, um símbolo. Poderia ser em uma biblioteca em meio à história escrita e o silêncio monástico. Poderia ser em um banheiro úmido num movimento que jamais se terminaria. Ou então numa rua movimentada, depois de admirar a visão última do pôr do sol no Guaíba. Estilhaçada pelos 11 andares - pois 4 andares não matam, deixam mais pobre. Pra ser honesto, não sei onde poderia ser seu fim. Só sei que é inevitável que acabe no chão. Na terra. No pó. O mesmo chão que na sua infância lhe era quadro negro e alicerce, e que lhe resfriava os pés 
quentes das corridas em volta da casa, agora lhe serve de caixa prego de lugar último. Sua sepultura.

Mas por quê? Matarei para não matar. Matarei Odete ou Cleusa de propósito só para provar um pouco do gosto da morte. Esse elo entre a concretude e a minha falta dela. 